ISSN 1392-3196 / e-ISSN 2335-8947

Zemdirbyste-Agriculture, vol. 102, No. 2 (2015), p. 185-192

DOI $10.13080 / \mathrm{z}-\mathrm{a} .2015 .102 .024$

\title{
Stability of tomato lycopene under thermal- and light- irradiation treatments in an oil-based model system
}

\author{
Dalia URBONAVIČIENÉ ${ }^{1,2}$, Pranas VIŠKELIS ${ }^{1}$, Jonas VIŠKELIS ${ }^{1}$, Česlovas BOBINAS ${ }^{1}$ \\ ${ }^{1}$ Institute of Horticulture, Lithuanian Research Centre for Agriculture and Forestry \\ Kauno g. 30, Babtai, Kaunas distr., Lithuania \\ E-mail: dalia.urbonaviciene@ktu.edu \\ ${ }^{2}$ Kaunas University of Technology \\ Radvilènų pl. 19, Kaunas, Lithuania
}

\begin{abstract}
The lycopene content in food may be increased by thermal and mechanical processing. Food processing is beneficial because it disrupts food matrices facilitating the release and solubilisation of lycopene resulting in increased carotenoid bioavailability for the formation of cis-isomers. A lycopene-rich and $\beta$-carotene oil-based system was used in this study. High-performance liquid chromatography (HPLC) and colour coordinates analyses were employed to analyse lycopene, its $c i s$-isomers and $\beta$-carotene stability of the following sample set after 28 days of storage: fridge temperature at $1 \pm 1{ }^{\circ} \mathrm{C}$ in absence of light (FT dark), ambient temperature at $20 \pm 1{ }^{\circ} \mathrm{C}$ in natural light with different day and night illumination (AT light), ambient temperature at $20 \pm 1^{\circ} \mathrm{C}$ in absence of light (AT dark), thermostatically controlled temperature at $37 \pm 1{ }^{\circ} \mathrm{C}$ in absence of light (TT dark) and thermostatically controlled temperature at $37 \pm 1{ }^{\circ} \mathrm{C}$ in UV irradiation (TT UV). The control sample in our study was lycopene enriched oil stored in the dark at $1 \pm 1{ }^{\circ} \mathrm{C}$ on day zero (0). The aim of this study was to create lycopene-enriched oil from tomato to investigate its stability and to prepare the recommendations to consumers for the storage conditions of this functional food. The results indicated that the trans-lycopene amount changed from $76.6 \%$ to $61.0 \%$ at ambient temperature (AT light and AT dark sample), and from $76.6 \%$ to $46.8 \%$ (TT dark) and $44.4 \%$ (TT UV) at $37 \pm 1{ }^{\circ} \mathrm{C}$. According to our investigation, the highest percentage of 5-cis-lycopene isomer in all samples was found after 28 days of storage. The TT UV samples had the most colour changes. Vegetable oil enriched with lycopene from tomatoes is a high quality food product that can supplement daily diet and enhance absorption of lycopene from the intestine.
\end{abstract}

Key words: $\beta$-carotene, degradation rate constant, isomerisation, lycopene, Lycopersicon esculentum.

\section{Introduction}

Tomato and tomato-based products are important agricultural production worldwide. More than $80 \%$ of tomatoes grown worldwide are processed into the products such as tomato juice, paste, puree, catsup, sauce and salsa (Gould, 1992).

Nowadays the development of more attractive functional food is important for the consumers' health. The relationship between diet and health has become an important request for the consumer. The demand for information about functional food has increased (Kaur, Das, 2011). The concentration of the lycopene, a carotenoid, is particularly high in tomatoes. Lycopene is important mainly due to its beneficial properties for human health. Lycopene protects humans from attack by pathogenic agents responsible for a number of chronic diseases, such as cardiovascular diseases, different types of cancer (digestive tract, cervix, breast, skin, bladder and prostate), hypertension, osteoporosis, neurodegenerative diseases, male infertility and even transmission of acquired immunodeficiency syndrome from mothers to babies (Hof et al., 2000).

The availability of lycopene from food may depend on several factors: 1) lycopene content of food may be increased by mechanical processing (Hof et al., 2000); 2) the bioavailability of lycopene is greatly increased by thermal (cooking or by commercial) processing (Bates, $2005)$; 3) the addition of lipids, such as vegetable oils, increases lycopene absorption (Shi, Le Maguer, $2000)$; 4) it has been reported that lycopene is more efficiently absorbed when tomato juice is warmed with a supplemental lipid (Shi, Le Maguer, 2000); 5) $\beta$-carotene in the same dish as lycopene causes an increase in the absorption of lycopene (Bates, 2005). Moreover, during exposure to thermoenergy, oxygen light, lycopene can undergo isomerisation and degradation. Isomerisation converts all-trans-isomers to cis-isomers and results in a reduction in the biological properties of lycopene (Preedy, Watson, 2008). Red tomatoes normally contain 
$94-96 \%$ of all-trans-lycopene. All-trans-lycopene is thermodynamically the most stable form (Gupta et al., 2010). Some authors have reported that the formation of cis-isomers of lycopene may increase biological activity (Bartkiene et al., 2013). Determination of the degree of lycopene isomerisation during processing and storage would provide a measurement of the potential health benefits of tomato-based foods (Preedy, Watson, 2008).

It is important to develop more attractive readyto-eat products to contribute to the increased consumption of fruit and vegetable products and their health benefits for the consumers, which should be attributed to food processing adaptation to enhance the bioavailability of nutrients (Martínez-Tomás et al., 2012). Additional information needs to be gathered on the thermal behaviour of lycopene before definitive answers conclusions can be drawn regarding its physical state and stability during processing and cooking. Little information is known about the stability of lycopene in supplemental form (Kopec et al., 2010).

The aim of this study was to create lycopeneenriched oil from tomato to investigate its stability and to prepare the recommendations to consumers for the storage conditions of this functional food.

\section{Material and methods}

Materials. The experiments were performed in 2013 at the Laboratory of Biochemistry and Technology of the Institute of Horticulture, Lithuanian Research Centre for Agriculture and Forestry. Fresh tomato (Lycopersicon esculentum L.) of the hybrid 'Admiro $\mathrm{F}_{1}$, (grown in the greenhouses of the Institute of Horticulture) and rapeseeds oil (Lithuania) were used. The tomatoes were red ripe, uniform in size, firm and undamaged. The HPLC-grade solvents, including hexane, methanol, methyl-tert-butyl ether and ethyl acetate, were obtained from "Sigma-Aldrich" (Germany).

Sample preparation. Lycopene-rich tomato extract in oil was prepared. Whole washed tomatoes were chopped into pieces and mixed for $3 \mathrm{~min}$ in a homogenous mass using an electric blender MMB 2000 UC ("Bosch", Germany). The puree was then mixed by a laboratory stirrer ER-10 ("VEB MLW Prufgerate", Germany) with virgin rapeseed oil using a volumetric ratio of $1: 1(\mathrm{v} / \mathrm{v})$. The temperature of the solution was stable during extraction $\left(20 \pm 1^{\circ} \mathrm{C}\right.$ ) (thermostat model 9100, "PolyScience", USA). After 2 hours, the oil phase was separated by a preparative centrifuge ЦРЛ1 ("Texnokom", Russia). The extract was poured into 20 unit $2 \mathrm{ml}$ vials, and the extract was divided into five groups. Stability of lycopene-rich oil extract was investigated during a 28-day storage period. Storage conditions were as follows: 1) fridge temperature at $1 \pm$ $1^{\circ} \mathrm{C}$ in absence of light (FT dark), 2) ambient temperature at $20 \pm 1^{\circ} \mathrm{C}$ in natural light with different day and night illumination (AT light), 3) ambient temperature at $20 \pm$ $1^{\circ} \mathrm{C}$ in absence of light (AT dark), 4) thermostatically controlled temperature at $37 \pm 1{ }^{\circ} \mathrm{C}$ in absence of light (TT dark), 5) thermostatically controlled temperature at $37 \pm 1^{\circ} \mathrm{C}$ in UV irradiation (TT UV). The control sample in our study was lycopene-enriched oil stored in the dark at $1 \pm 1{ }^{\circ} \mathrm{C}$ on day zero (0). The samples were stored in hermetically sealed containers. The control sample and all lycopene-enriched oil samples were prepared for HPLC analysis after storage. The oil extract was diluted with hexane using a volumetric ratio of $1: 8(\mathrm{v} / \mathrm{v})$. HPLC analysis of the lycopene-enriched oil indicated the presence of $\beta$-carotene. The trans-lycopene (HPLC grade; all-trans-lycopene from tomato powder) and $\beta$-carotene (HPLC grade, synthetic, $\geq 93 \%$ purity, powder) standards were used ("Sigma-Aldrich", Germany).

High-performance liquid chromatography (HPLC) analysis of lycopene isomers and $\beta$-carotene. The stability of all-trans-lycopene and $\beta$-carotene in the extracts was analysed by the slightly modified reversed phase HPLC method of Ishida (Ishida et al., 2001; Urbonavičiené, Viškelis, 2013) connected to a detector Waters 2489 UV/Vis ("Water Corporation", USA). Detection of lycopene and $\beta$-carotene was at 473 $\mathrm{nm}$. The mobile phase consisted of methanol, methyltert-butyl ether and ethyl acetate at a flow rate of 1.5

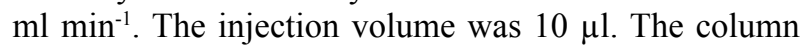
temperature was $28^{\circ} \mathrm{C}$. The samples were filtered through a $0.45 \mathrm{~mm}$ polyvinylidene fluoride (PVDF) syringe filter ("Millipore", USA) before injection. To quantify lycopene in the extract samples, a calibration curve was generated using an authentic all-trans-lycopene standard. Levels of cis-lycopene isomers are given in all-translycopene equivalents.

Colour measurements. Colour change was measured by a spectrophotometer MiniScan XE Plus (HunterAssociates Laboratory Inc., USA) (Urbonaviciene et al., 2012). The apparatus (45/0 geometry, illuminant D65, 10 observer) was calibrated with a standard tile $(\mathrm{X}=$ 81.3, $\mathrm{Y}=86.2$ and $\mathrm{Z}=92.7)$. A cylindrical glass cell filled with $3 \mathrm{ml}$ of sample was placed on the top of the light source (2.5 cm opening) and covered with a white plate. Inclusion of air bubbles was prevented. The recorder $X$, $\mathrm{Y}$ and $\mathrm{Z}$ tristimulus values were converted to CIE L*, $\mathrm{a}^{*}$ and $b^{*}$ colour values. Regarding light reflection, the $\mathrm{L}^{*}$, $a^{*}$ and $b^{*}$ parameters (lightness, redness and yellowness indices, respectively, according to CIE $\mathrm{L}^{*} \mathrm{a} * \mathrm{~b} *$ scale) were measured, and chroma (C) (1), hue angle $\left(\mathrm{h}^{\circ}\right)(2)$ and the total colour difference $(\Delta \mathrm{E})(3)$ were calculated:

$$
\begin{aligned}
& C=\left(a^{* 2}+b^{* 2}\right)^{1 / 2} \\
& h^{o}=\arctan \left(\frac{b^{*}}{a^{*}}\right) \\
& \Delta E=\sqrt{\left(\Delta L^{*}\right)^{2}+\left(\Delta a^{*}\right)^{2}+\left(\Delta b^{*}\right)^{2}}
\end{aligned}
$$

The $\mathrm{L}^{*}, \mathrm{C}, \mathrm{a}^{*}$ and $\mathrm{b}^{*}$ volumes were measured in NBS units, and hue angle was measured in degrees from 0 to $360^{\circ}$. A NBS unit is a unit of the USA National Standard Bureau, and it corresponds to one threshold of colour distinction power, i.e. the least distinction in colour that the trained human eye can notice (McGuire, 1992). The colour parameters were processed with the software Universal V.4-10 program. Colour measurements were performed in triplicate.

Measurement and monitoring of environmental parameters. The temperature and illumination were recorded using a HOBO Pendant Temperature/Light Data 
Logger 8K-UA-02-08 (“Onset", Finland) at 6-h intervals and were processed with software HOBOware Pro.

Statistical analysis. All experiments were replicated three times and the results were expressed as the means \pm standard deviations. Statistical analysis was performed using software SPSS, version 16.0 (USA). Data were analysed using one-way ANOVA followed by Duncan's test. The confidence interval was $95 \%$ $(p<0.05)$.

\section{Results and discussion}

The development of suitable processing conditions and techniques can be used to stabilise lycopene and other carotenoids in the tomato products during the production and storage, and these are important issues for process optimisation (Chen et al., 2009). The effects of thermal- and light-irradiation processing on lycopene stability in an oil-based food model system have not yet been completely investigated.
The aim of our study was to investigate if the storage conditions lead to instability and change of the lycopene-enriched extract because it is important to provide consumers with advice on storage conditions for the lycopene-enriched oil and to know the main factors that affect lycopene isomerisation in an oil-based model system. The storage conditions of samples were selected advisedly. According to Rodriguez-Amaya (2001), exposure to light, especially direct sunlight or ultraviolet light induces trans-cis photoisomerisation and photodestruction of carotenoids.

Figure 1 shows the temperature and the illumination in the storage conditions of the samples during the test period. The illumination imitated the light effect from daylight (200-400 Lux) in addition to the aggressive UV radiation (2000-3000 Lux). It was important to clarify the temperature under which the extract was stable. Lycopene stability measurements were carried out in the temperature range from $1 \pm 1^{\circ} \mathrm{C}$ to
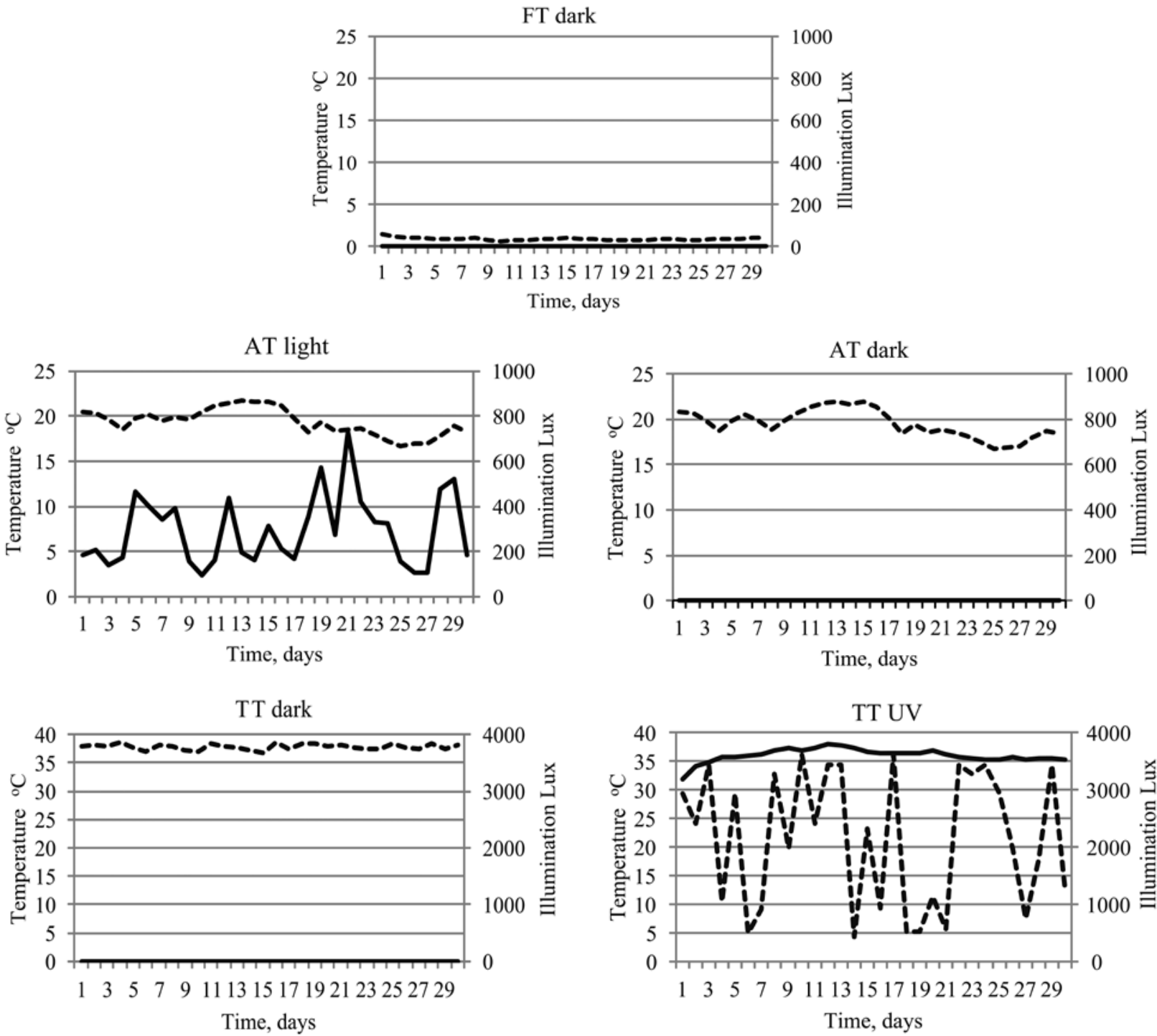

FT dark - fridge temperature at $1 \pm 1^{\circ} \mathrm{C}$ in absence of light; AT light - ambient temperature at $20 \pm 1{ }^{\circ} \mathrm{C}$ in natural light with different day and night illumination; AT dark - ambient temperature at $20 \pm 1{ }^{\circ} \mathrm{C}$ in absence of light; TT dark - thermostatically controlled temperature at $37 \pm 1^{\circ} \mathrm{C}$ in absence of light; TT UV - thermostatically controlled temperature at $37 \pm 1{ }^{\circ} \mathrm{C}$ in UV irradiation

Figure 1. Storage conditions of the sample set 
$37 \pm 1^{\circ} \mathrm{C}$. The samples were stored in the dark at $1 \pm 1^{\circ} \mathrm{C}$ in order to simulate storage conditions in the refrigerator. The samples were stored at ambient temperature (20 $\pm 1^{\circ} \mathrm{C}$ ) in the dark or light in order to simulate storage conditions in the cupboard or on the kitchen counter. The samples were stored at $37 \pm 1^{\circ} \mathrm{C}$ in the dark or light in order to simulate extreme storage conditions in the cupboard or on a counter next to working stove/oven.

Aiming to develop a technological process that yields a stable lycopene-enriched oil, we first investigated lycopene isomerisation during temperature and illumination changes in an oil-based model system. Lycopene is biosynthesised in plants mainly (above $90 \%$ ) as an all-trans-isomer (Lambelet et al., 2009). In our study lycopene found in tomatoes consists of $92 \%$ of all-trans-isomers. Many researchers suggest that lycopene undergoes geometrical isomerisation during food processing, which increases the proportion of cis-isomers (Schierle et al., 1996; Shi et al., 2002).
In our study, cis- and trans-isomers of lycopene were indentified, based on spectral characteristics and $\mathrm{Q}$ ratios as reported in a previous study (Lee, Chen, 2001). The comparison of all treatments, namely, FT dark, AT light, AT dark, TT dark and TT UV, showed that various cisand trans-isomers of lycopene, including 5-cis, were present. Our investigation showed that the 5-cis-isomer changed distinctively during lycopene storage compared to the other lycopene isomers. Our results demonstrated that the 5-cis-isomer of lycopene indicates the main isomerisation process because this isomer was dominant in all the samples during the 28 days of storage. In our study, the stability of lycopene isomers in an extract was investigated. Figures 2 and 3 show a decrease in the alltrans-lycopene-isomer of lycopene and a simultaneous increase in 5-cis-isomers.

The lycopene trans- and 5-cis-isoform in the FT dark treatment was stable during 28 days, it can be because the temperature was $1 \pm 1^{\circ} \mathrm{C}$ and there was no

$$
\begin{gathered}
\text { FT dark: } \mathrm{y}=-0.507 \mathrm{x}+77.337 \text { AT light: } \mathrm{y}=-3.898 \mathrm{x}+78.758 \quad \text { AT dark: } \mathrm{y}=-3.849 \mathrm{x}+79.229 \\
R^{2}=0.929 \quad \text { TT UV: } \mathrm{y}=-8.359 \mathrm{x}+78.085 \\
\begin{array}{cc}
R^{2}=0.723 & R^{2}=0.785 \\
\text { TT dark: } \mathrm{y}=-6.611 \mathrm{x}+74.417 & \text { Th } \\
R^{2}=0.690 &
\end{array}
\end{gathered}
$$

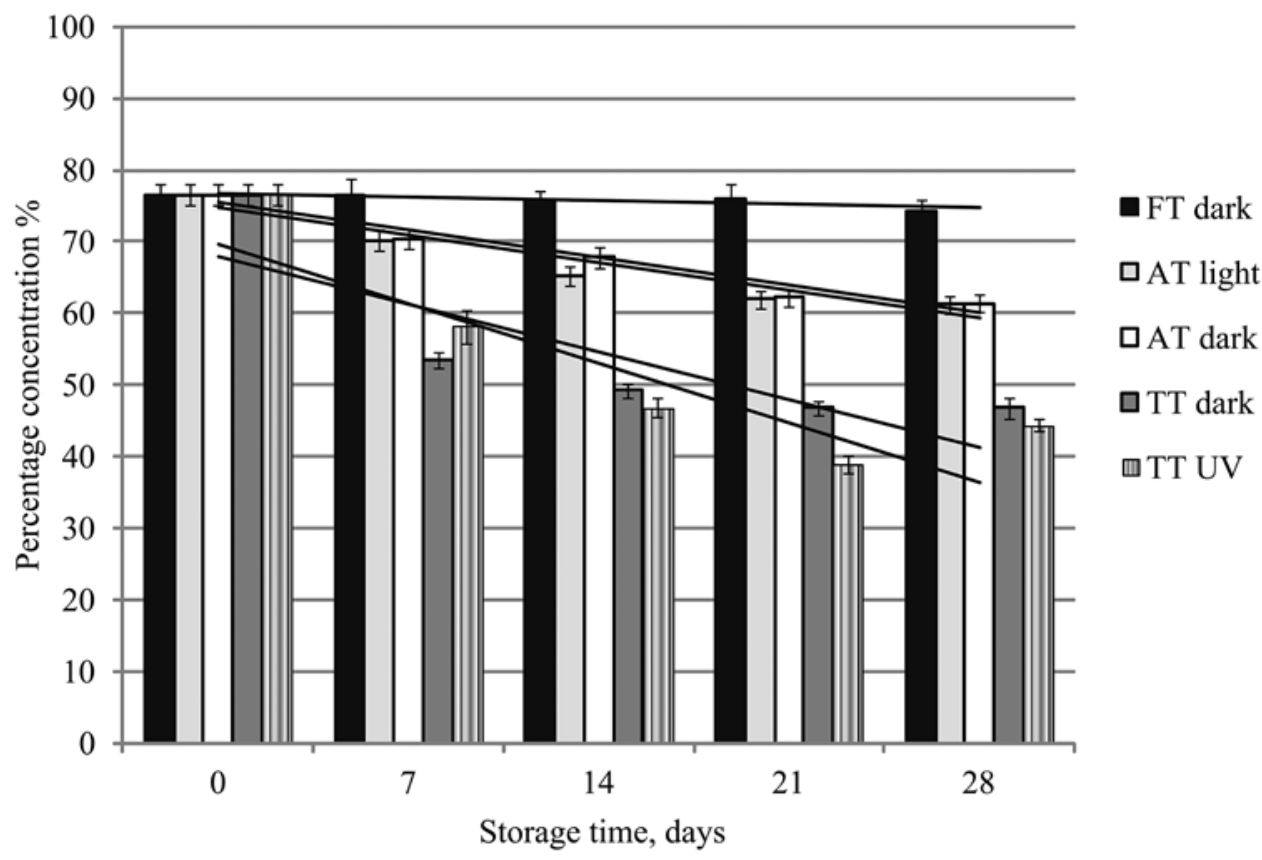

Figure 2. Trans-lycopene concentration as a percentage of total lycopene during illumination and temperature impact after 28 days in lycopene-enriched oil

illumination impact (0 Lux). When comparing the $20 \pm 1^{\circ} \mathrm{C}$ temperature (AT light and AT dark samples) and the $37^{\circ} \mathrm{C}$ temperature (TT dark and TT UV samples), the results showed that the temperature impact caused degradation of trans- and cis-lycopene isomerisation at the same time. The trans-lycopene content decreased significantly ( $p<$ 0.05 ) in the TT dark and TT UV samples with increasing temperature. The trans-lycopene amount changed from $76.6 \%$ to $61.0 \%$ at AT light and AT dark samples and from 76.6 to 46.8 and $44.4 \%$ at TT dark and TT UV samples, respectively. Therefore, trans-lycopene degradation in the AT light and dark samples exhibited linear decline patterns with a correlation coefficient $\left(R^{2}\right)$ greater than 0.92 for the plot of the concentration of trans-lycopene versus time. However, this linear characteristic did not fit well for the TT dark and TT UV samples with $R^{2}$ values ranging from 0.69 to 0.78 . It is possible that trans-lycopene undergoes not only isomerisation, but also degradation, which may cause a misrepresentation of the results.

According to the results of this study, the 5-cislycopene isomer amount increased in all samples after 28 days (Fig. 3). The 5-cis-lycopene isomer amount indicated that the trans-lycopene isomer degradation (\%) during the temperature and light impacts was 3.11, 10.98, 9.11, 19.10 and 20.68 for the FT dark, AT light, AT dark, TT dark and TT UV samples, respectively, after 28 days. 

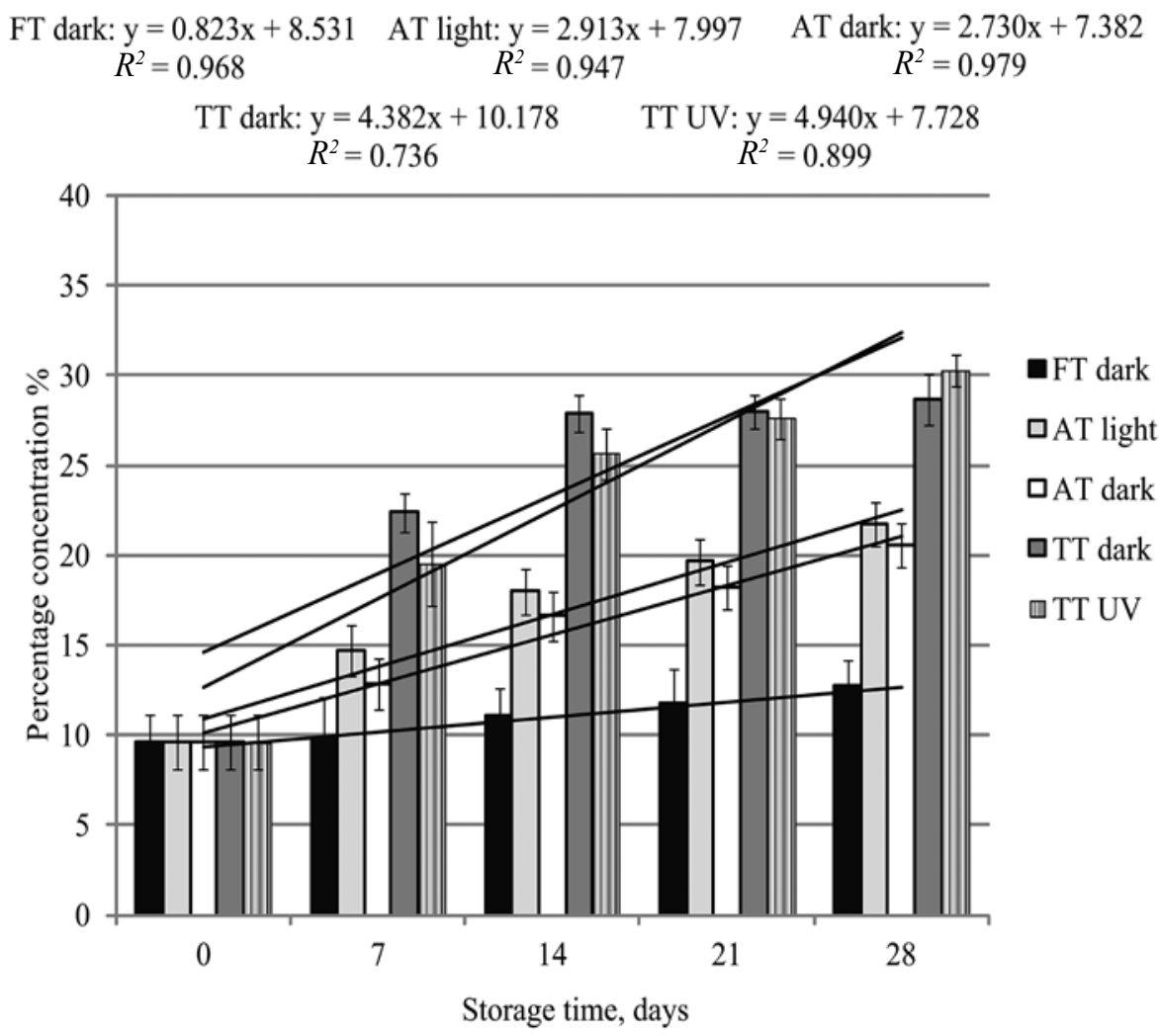

Figure 3. 5-cis-lycopene concentration as a percentage of total lycopene during illumination and temperature impacts after 28 days in lycopene-enriched oil

The main change (more than $20 \%$ ) of the 5 -cis-lycopene isomer in the oil was due to the influence of UV rays in the TT UV samples. The decreased of amount of translycopene may have been due to isomerisation, resulting from additional energy (temperature and/or light) input, which led to unstable, energy-rich situations (Shi, Le Maguer, 2000). Our results indicated that formation of the stable 5-cis-lycopene isomer in the supplement allowed bioavailability of lycopene. According to Roldán-Gutiérrez and de Castro (2007), cis-lycopene isomers are also less likely to crystallise or to aggregate and may therefore be more efficiently solubilised in lipophilic solutions and more readily transported within cells or between tissues.

It is difficult to compare our results with those of recent investigations because little is known about the stability of lycopene in a supplemental form and the temperatures used in previous studies were either very high - from $80^{\circ} \mathrm{C}$ to $180^{\circ} \mathrm{C}$ (Shi et al., 2002; Chen et al., 2009) or low $-\sim 24^{\circ} \mathrm{C}$ (Qiu et al., 2006).

In our study, in the TT dark sample stored at $37^{\circ} \mathrm{C}$ (the highest temperature used in our study) the percentage of trans-lycopene isomer decreased from $76.6 \%$ to $46.4 \%$ and the percentage of 5 -cis-lycopene isomer increased from $9.6 \%$ to $28.7 \%$. The results show that higher temperature is directly correlated with decreasing amount of trans-lycopene isomer.

These data suggest that not only higher temperatures but also low temperatures, illumination and storage time are directly correlated with increasing lycopene losses and that thermal treatment leads to a significant decrease in the concentrations of all-tranlycopene. In conclusion, storage time in soft temperatures (e.g., $20^{\circ} \mathrm{C}$ or $37^{\circ} \mathrm{C}$ ) and natural light illumination can be used as an alternative process, which is clean and energyefficient compared with many conventional processes. Measurement of the degradation of total lycopene and the stability differences of the lycopene trans-and cis-isomers is useful to model the kinetics data. The stability of lycopene-enriched oil was investigated in our study. The degradation rate constant $(k)$ of the total lycopene content in the oil-based model system under different treatment conditions was fitted to a first-order kinetic reaction model as shown in Figure 4. The kinetic degradation rate of total lycopene in the oil-based model samples showed a good-fit kinetic model with a linear correlation $\left(R^{2}\right)$ range of $0.922-0.980$ for the AT light, AT dark and TT dark samples, in contrast to the FT dark and TT UV samples with $R^{2}$ values of 0.571 and 0.707 , respectively. The kinetic degradation rate constant $(k$ in day $^{-1}$ ) resulted in total lycopene loss rates (in mg $100 \mathrm{~g}^{-1}$ in oil) of $0.0009,0.0067,0.0034,0.0088$ and 0.0211 during the temperature and light impact in the FT dark, AT light, AT dark, TT dark and TT UV samples, respectively, in the oil-based model. The largest kinetic constant $(k=$ 0.0211 ) of the total lycopene degradation was for the TT UV sample.

According to results of this study, the reasons for the differences in kinetic constants are unclear. The main explanation could be related to the fact that there was only a slight but not significant change in the total lycopene content in the FT dark sample, so the linear relationship did not exist. In contrast, highly significant changes were found in the TT UV sample because UV irradiation could have led to the degradation of total lycopene content. Moreover, the degradation products (which were not investigated) may have influenced the kinetic constant. 


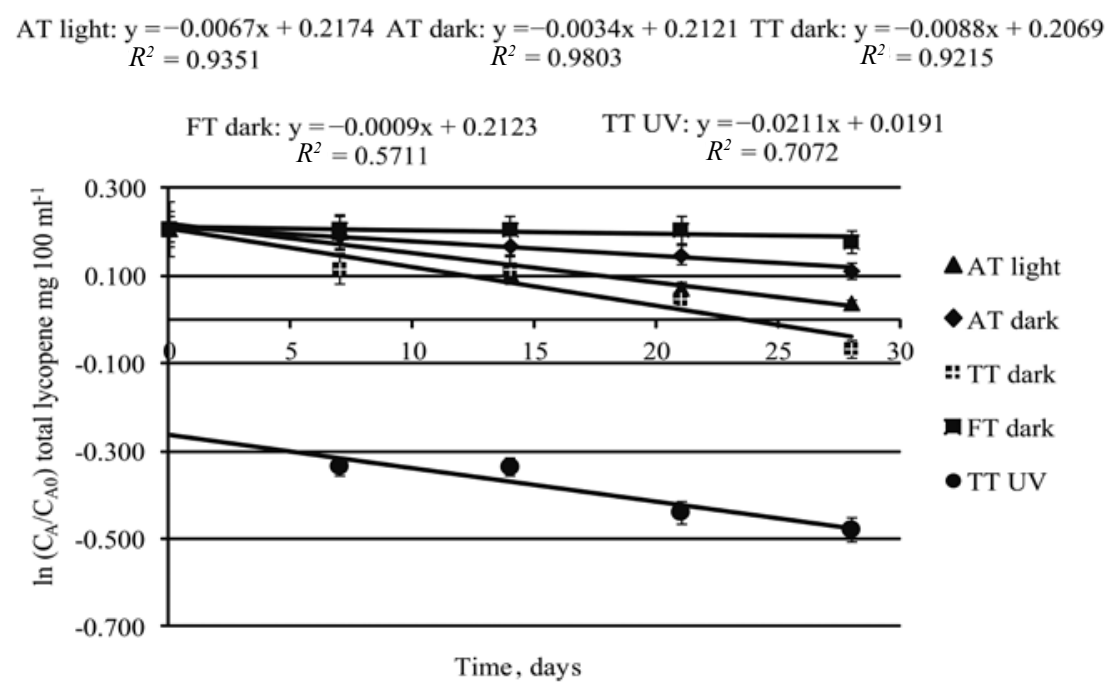

Note. The results are from the means of three HPLC analyses of three extracts; $\mathrm{C}_{\mathrm{A}}-$ the total amount of lycopene after storage, $\mathrm{C}_{\mathrm{A} 0}$ - the initial amount of lycopene.

Figure 4. A plot of $\ln$ (concentration) vs time data for a first-order reaction of total lycopene

The kinetics of total lycopene degradation is complex, and the data depends on the other components in the oil-based system. Interactions with other carotenoids are complex and have only partly been studied. For example, $\beta$-carotene in the same dish increases the absorption of lycopene (Bates, 2005). Thus, in our studies using the oil model system and HPCL analyses, $\beta$-carotene was also found in the lycopene-enriched oil extract, which confirms that the lycopene-enriched oil-based model system has consumer health benefits. The high $R^{2}$ value $(0.973)$ of total $\beta$-carotene in the AT dark samples indicated that the kinetics of the reaction followed as a first-order reaction (Fig. 5), and the slope provided the pseudo first-order rate constant. Because the concentration of the reactant is decreased, the slope was negative. Therefore, we used the absolute value to obtain the result for the rate constant. The $R^{2}$ value for a linear regression between the concentration and time data showed a poor correlation for the TT dark and FT dark samples with values of 0.316 and 0.334 , respectively, indicating that the kinetics of this reaction was not pseudo first-order. Therefore, the natural logarithms of the concentration values were calculated, and the slope was determined. The kinetic degradation rate constant $(k$ in day $\left.^{-1}\right)$ indicated that the rate of total $\beta$-carotene loss (in mg $100 \mathrm{~g}^{-1}$ in oil) during the temperature and light impact was $0.0007,0.0034,0.0004,0.0001$ and 0.0056 in the oil-based model for the FT dark, AT light, AT dark, TT dark and TT UV samples, respectively. The largest kinetic constant $(k=0.0056)$ for the total $\beta$-carotene degradation was found for the TT UV sample.

Consumers use the intensity of the red colour as an index of quality for tomato-based products (Kopec et al., 2010). The changes in colour values ( $\mathrm{a}^{*}$ and $\mathrm{b}^{*}$ ratio; hue angle, $\mathrm{h}^{\circ}$; chroma $\mathrm{C}$ and colour difference $(\Delta \mathrm{E})$ of the control and samples over the course of 28 days

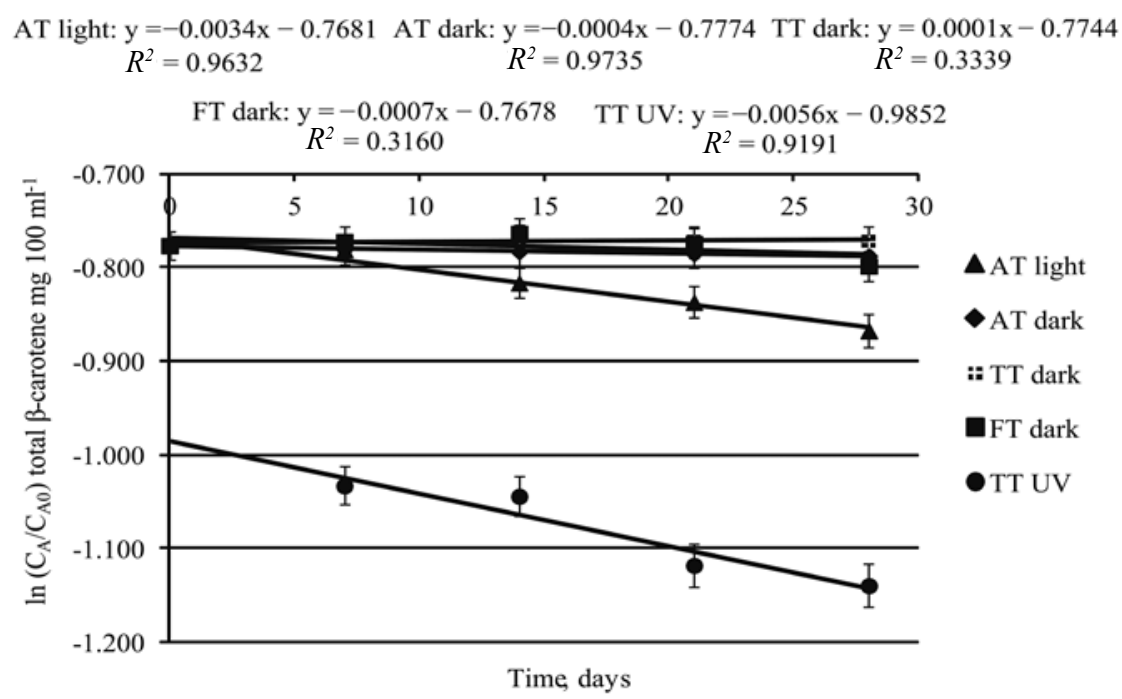

Note. The results are from the means of three HPLC analyses of three extracts; $\mathrm{C}_{\mathrm{A}}$ - the total amount of $\beta$-carotene after storage, $\mathrm{C}_{\mathrm{A} 0}-$ the initial amount of $\beta$-carotene.

Figure 5. A plot of $\ln$ (concentration) vs time data for a first-order reaction of total $\beta$-carotene 
of storage at 1,20 and $37 \pm 1{ }^{\circ} \mathrm{C}$ storage temperatures are shown in Table. In comparison to the control sample at day 0 , the colour of all of the processed samples (AT light, AT dark, TT dark, FT dark and TT UV) changed as a function of storage temperature, illumination and time, but the differences were not significant. The $a^{*}$ and $b^{*}$ ratio indicated the colour changes of the tomato product from red to yellow. A slight difference of $a^{*}$ and $b^{*}$ ratio colour parameters in the sample set was found after 28 days. In comparison with other samples, the $\mathrm{a}^{*}$ and $\mathrm{b}^{*}$ ratio differences of the TT UV sample were significant (from control sample; 0.64 to 0.54 after 28 days). The hue angle indicated that the lycopene-rich nutritional supplement did not have a pure red colour. The hue angle varied from $56.2^{\circ}$ (AT light) to $61.9^{\circ}$ (TT UV) $\left(90^{\circ}\right.$ would mean that the sample is yellow, and $0^{\circ}$ indicates completely red) after 28 days. The results suggested that all samples had a reddish-yellow colour after 28 days compared to the colour at day 0 . The chroma value indicates the degree of saturation of colour and is proportional to the strength of the colour. There were no differences in the chroma value between day 0 and after 28 days in the TT UV sample (35.13 and 36.3, respectively).

Table. The changes in colour values ( $\mathrm{a}^{*}$ and $\mathrm{b}^{*}$ ratio; chroma, $\mathrm{C}$; hue angle, $\mathrm{h}^{\circ}$; colour difference, $\Delta \mathrm{E}$ ) of the control and samples over the course of 28 days of storage at 1,20 and $37 \pm 1^{\circ} \mathrm{C}$ temperatures

\begin{tabular}{|c|c|c|c|c|c|c|c|c|}
\hline \multirow{3}{*}{$\begin{array}{l}\text { Sample name } \\
\text { Control sample }\end{array}$} & \multicolumn{8}{|c|}{ Colour parameters } \\
\hline & \multicolumn{2}{|c|}{$a^{*}$ and $b^{*}$ ratio } & \multicolumn{2}{|r|}{$\mathrm{C}$} & \multicolumn{2}{|c|}{$\mathrm{h}^{\circ}$} & \multirow{2}{*}{\multicolumn{2}{|c|}{$\begin{array}{c}\Delta \mathrm{E} \\
0.00 \\
\end{array}$}} \\
\hline & 0.64 & \pm 0.025 & 35.13 & \pm 1.40 & 57.46 & \pm 2.18 & & \\
\hline \multicolumn{9}{|l|}{ After 28 days } \\
\hline AT light & 0.65 & $\pm 0.028 \mathrm{a}$ & 35.39 & $\pm 1.42 \mathrm{a}$ & 56.23 & $\pm 2.06 \mathrm{a}$ & 0.33 & $\pm 0.013 \mathrm{a}$ \\
\hline AT dark & 0.64 & $\pm 0.020 \mathrm{a}$ & 35.02 & $\pm 1.05 \mathrm{ab}$ & 57.15 & $\pm 2.29 \mathrm{a}$ & 0.22 & $\pm 0.011 \mathrm{~b}$ \\
\hline TT dark & 0.59 & $\pm 0.026 \mathrm{ab}$ & 35.07 & $\pm 1.58 \mathrm{a}$ & 59.10 & $\pm 1.48 \mathrm{~b}$ & 1.35 & $\pm 0.054 \mathrm{c}$ \\
\hline FT dark & 0.66 & $\pm 0.030 \mathrm{a}$ & 34.86 & $\pm 0.87 \mathrm{~b}$ & 56.15 & $\pm 2.17 \mathrm{a}$ & 0.82 & $\pm 0.028 \mathrm{c}$ \\
\hline TT UV & 0.54 & $\pm 0.025 \mathrm{c}$ & 36.32 & $\pm 1.09 \mathrm{ac}$ & 61.86 & $\pm 1.85 \mathrm{bc}$ & 3.69 & $\pm 0.148 \mathrm{~d}$ \\
\hline
\end{tabular}

Notes. The numbers are means followed by standard deviations $(\mathrm{n}=3)$. Means within a column with different superscript letters are significantly different $(p \leq 0.05)$. AT light - ambient temperature at $20 \pm 1{ }^{\circ} \mathrm{C}$ in natural light with different day and night illumination; AT dark - ambient temperature at $20 \pm 1^{\circ} \mathrm{C}$ in absence of light; TT dark - thermostatically controlled temperature at $37 \pm 1^{\circ} \mathrm{C}$ in absence of light; FT dark - fridge temperature at $1 \pm 1^{\circ} \mathrm{C}$ in absence of light; TT UV - thermostatically controlled temperature at $37 \pm 1^{\circ} \mathrm{C}$ in UV irradiation.

Our study indicated that the chroma value of the TT UV sample increased until day 21 and then decreased until the end of storage. The total colour difference $(\Delta \mathrm{E})$ was more than 3 in the TT UV sample after 28 days. According to Lee and Coates (2003), a value of $\Delta \mathrm{E} \approx 2$ represents a noticeable colour difference, and $\Delta \mathrm{E}>3$ for many products is unacceptable according to consumers. Among the treatments, the FT dark, AT light, AT dark and TT dark samples had better colour retention, and the TT UV samples had the most colour changes. The FT dark, AT dark, AT light and TT dark samples had no colour loss.

\section{Conclusions}

1. Higher temperature has a greater influence on lycopene isomerisation (change from trans- to cisisoforms) than light irradiation. The percentage of translycopene changed from $76.6 \%$ (control) to $61 \%$ at $20^{\circ} \mathrm{C}$ (at AT light and AT dark) and to $46.8 \%$ and $44.4 \%$ at $37^{\circ} \mathrm{C}$ (at TT dark and TT UV).

2. The highest percentage of 5-cis-lycopene isomer in all samples was found after 28 days of storage. The percentage of 5-cis-lycopene changed from 9.6\% (control) to 12.7, 21.7, 20.6, 28.7 and $30.3 \%$ for the FT dark, AT light, AT dark, TT dark and TT UV samples, respectively. The highest increase in 5-cis-lycopene isomer was found in the oil that was stored in UV light at $37^{\circ} \mathrm{C}$.

3 . The ratio of $a^{*}$ and $b^{*}$ colour coordinates of all the investigated samples (AT light, AT dark, TT dark, FT dark and TT UV) changed as a function of storage temperature, illumination and time; however, the differences were not significant. The highest total colour difference $(\Delta \mathrm{E})$ was found between the control sample and TT UV samples, whereas FT dark, AT light, AT dark and TT dark samples had better colour retention.
4. The addition of tomato extracts to vegetable oil might increase the level of lycopene in a human diet and enhance its bioavailability. The optimum storage conditions for lycopene-enriched oil were at $20^{\circ} \mathrm{C}$ in the dark.

\section{Acknowledgments}

This work was partly supported by a grant from the Research Council of Lithuania, No. SVE-02/2011.

Received 26082014

Accepted 29012015

\section{References}

Bartkiene E., Vidmantiene D., Juodeikiene G., Viskelis P., Urbonaviciene D. 2013. Lactic acid fermentation of tomato: effects on cis/trans lycopene isomer ratio, $\beta$-carotene mass fraction and formation of $\mathrm{L}(+)$ - and $\mathrm{D}(-)$-lactic acid. Food Technology and Biotechnology, 51 (4): 471-478

Bates J. C. 2005. Lycopenes and related compounds. Caballero B., Allen L. (eds). Encyclopedia of Human Nutrition $\left(2^{\text {nd }}\right.$ ed.), p. $184-190$

Chen J., Shi J., Xue S. J., Ma Y. 2009. Comparison of lycopene stability in water- and oil-based food model systems under thermal- and light-irradiation treatments. LWT-Food Science and Technology, 42 (3): 740-747 http://dx.doi.org/10.1016/j.lwt.2008.10.002

GouldW.A. 1992. Tomatoproduction,processingand technology, 535 p. http://dx.doi.org/10.1533/9781845696146

Gupta R., Balasubramaniam V. M., Schwartz S. J., Francis D. M. 2010. Storage stability of lycopene in tomato juice subjected to combined pressure-heat treatments. Journal of Agricultural and Food Chemistry, 58 (14): 8305-8313

Hof van het K. H., West C. E., Weststrate J. A., Hautvast J. G. A. J. 2000. Dietary factors that affect the bioavailability of carotenoids. The Journal of Nutrition, 130 (3): 503-506 
Ishida B. K., Ma J., Chan B. 2001. A simple, rapid method for HPLC analysis of lycopene isomers. Phytochemical Analysis, 12 (3): 194-198

Kaur S., Das M. 2011. Functional foods: an overview. Food Science and Biotechnology, 20 (4): 861-875

Kopec R., Schwartz S. J., Hadley C. 2010. Lycopene. Coates M. et al. (eds). Encyclopedia of Dietary Supplements, p. 504-517

Lambelet P., Richelle M., Bortlik K., Franceschi F., Giori A. M. 2009. Improving the stability of lycopene $Z$-isomers in isomerised tomato extracts. Food Chemistry, 112 (1): $156-161$

Lee H. S., Coates G. A. 2003. Effect of thermal pasteurization on Valencia orange juice color and pigments. LWT-Food Science and Technology, 36 (1): 153-156

Lee M. T., Chen B. H. 2001. Separation of lycopene and its cis isomers by liquid chromatography. Chromatographia, 54 (9-10): 613-617

Martínez-Tomás R., Peréz-Llamas F., Sánchez-Campillo M., González-Silvera D., Cascales A. I., García-Fernández M., López-Jiménez J. Á., Zamora Navarro S., Burgos M I., López-Azorín F., Wellner A., Avilés Plaza F., Bialek L., Alminger M., Larqué E. 2012. Daily intake of fruit and vegetable soups processed in different ways increases human serum $\beta$-carotene and lycopene concentrations and reduces levels of several oxidative stress markers in healthy subjects. Food Chemistry, 134 (1): 127-133 http://dx.doi.org/10.1016/j.foodchem.2012.02.078

McGuire R. G. 1992. Reporting of objective color measurements. Horticultural Science, 27 (12): 1254-1255
Preedy V. R., Watson R. R. 2008. Lycopene: nutritional, medicinal and therapeutic properties, $472 \mathrm{p}$.

Qiu W., Jiang H., Wang H., Gao Y.2006. Effect of high hydrostatic pressure on lycopene stability. Food Chemistry, 97 (3): 516-523 http://dx.doi.org/10.1201/9781439843390

Rodriguez-Amaya D. B. 2001. A guide to carotenoids analysis in foods, $71 \mathrm{p}$.

Roldán-Gutiérrez R. J. M., de Castro M. D. L. 2007. Lycopene: the need for better methods for characterization and determination. Trends in Analytical Chemistry, 26 (2): 163-170 http://dx.doi.org/10.1016/j.trac.2006.11.013

Schierle J., Bretzel W., Bühler I., Faccin N., Hess D., Steiner H., Schüep W. 1996. Content and isomeric ratio of lycopene in food and human blood plasma. Food Chemistry, 59 (3): 459-465

Shi J., Le Maguer M. 2000. Lycopene in tomatoes: chemical and physical properties affected by food processing. Critical Reviews in Biotechnology, 20 (4): 293-334 http://dx.doi.org/10.1080/07388550091144212

Shi J., Le Maguer M., Bryan M. 2002. Lycopene from tomatoes. Shi J. et al. (eds). Functional foods: biochemical and processing aspects. Boca Raton, USA, vol. 2, p. 135-167

Urbonaviciene D., Viskelis P., Viskelis J., Jankauskiene J., Bobinas C. 2012. Lycopene and $\beta$-carotene in non-blanched and blanched tomatoes. Journal of Food, Agriculture and Environment, 10 (2): 142-146

Urbonavičienè D., Viškelis P. 2013. Application of HPLC method for a determination of lycopene and $\beta$-carotene in tomatoes. Sodininkystè ir daržininkystè, 32 (1-2): 77-90 (in Lithuanian)

ISSN 1392-3196 / e-ISSN 2335-8947

Zemdirbyste-Agriculture, vol. 102, No. 2 (2015), p. 185-192

DOI 10.13080/z-a.2015.102.024

\title{
Pomidorų likopeno stabilumas esant skirtingoms temperatūroms ir apšvitoms aliejinėje modelinėje sistemoje
}

\author{
D. Urbonavičienè ${ }^{1,2}$, P. Viškeliss ${ }^{1}$, J. Viškelis ${ }^{1}, \check{C}$. Bobinas ${ }^{1}$ \\ ${ }^{1}$ Lietuvos agrarinių ir miškų mokslų centro Sodininkystès ir daržininkystès institutas \\ ${ }^{2}$ Kauno technologijos universitetas
}

\section{Santrauka}

Likopeno įsisavinimas iš maisto produktų nèra pakankamas. Nustatyta, kad geriau ịsisavinami ne natūraliai aptinkami trans-likopeno izomerai, o cis-izomerai. Maisto perdirbimas yra naudingas tuo, kad didejant likopeno cis-izomerų kiekiui, gerèja jo įsisavinimas. Tirta likopenu ir $\beta$ karotenu papildyta aliejinè modelinè sistema. Taikant efektyviają skysčių chromatografiją ir spalvų koordinačių analizę, tirtas likopeno, likopeno trans- bei cis-izomerų ir $\beta$ karoteno stabilumas bandiniuose skirtingomis laikymo 28 dienas sąlygomis: šaldytuve $1 \pm 1^{\circ} \mathrm{C}$ temperatūroje, tamsoje (FT tamsoje), kambario temperatūroje $-20 \pm 1{ }^{\circ} \mathrm{C}$, natūralioje šviesoje, kuri dienos ir nakties metu buvo skirtinga (AT šviesoje), kambario temperatūroje $-20 \pm 1^{\circ} \mathrm{C}$, tamsoje (KT tamsoje), termostatuojant $37 \pm 1{ }^{\circ} \mathrm{C}$ temperatūroje, tamsoje (TT tamsoje) ir termostatuojant $37 \pm 1{ }^{\circ} \mathrm{C}$ temperatūroje, šviesos šaltinis - ultravioletine lempa (TT UV). Kontrolinis bandinys buvo likopenu papildytas aliejus, laikytas tamsoje $1 \pm 1{ }^{\circ} \mathrm{C}$ temperatūroje eksperimento pradžioje ( 0 diena). Tyrimo tikslas - sukurti likopenu papildytą maisto papildą, ištirti jo stabilumą ir parengti rekomendacijas vartotojams, kokiomis optimaliomis sąlygomis laikyti ši maisto papildą. Tyrimo rezultatai parodè, kad trans-likopeno kiekis pakito nuo 76,6 iki 61,0\% kambario temperatūroje (AT šviesoje ir AT tamsoje) ir nuo 76,6 iki 46,8\% (TT tamsoje) ir iki 44,4\% (TT UV) esant $37{ }^{\circ} \mathrm{C}$ temperatūrai. Tyrimu duomenys rodo, kad, palyginus su kitais izomerais, 5-cis-izomero kiekis labiausiai kito likopeno laikymo metu. TT UV mėginiuose nustatyti didžiausi spalvų pokyčiai. Likopeno iš pomidorų turintis aliejus yra geros kokybės maisto papildas, kuris gali papildyti maisto racioną ir pagerinti likopeno įsisavinimą.

Reikšminiai žodžiai: $\beta$ karotenas, izomerizacija, likopenas, Lycopersicon esculentum, reakcijos greičio konstanta. 